RESEARCH ARTICLE

\title{
Potential Utilization Analysis of River Waste in Jakarta, Indonesia
}

\author{
Rahajeng Hasna Safira ${ }^{1}$, Mega Mutiara Sari ${ }^{1, *}$ (D), Suprihanto Notodarmojo ${ }^{1}$, \\ Takanobu Inoue ${ }^{2}$, Regil Kentaurus Harryes ${ }^{3}$ \\ ${ }^{1}$ Department of Environmental Engineering, Universitas Pertamina, Jakarta, 12220, Indonesia \\ ${ }^{2}$ Department of Architecture and Civil Engineering, Toyohashi University of \\ Technology, Toyohashi, 441-8580, Japan \\ ${ }^{3}$ Department of Aquatic Product Technology, Faculty of Vocational, Universitas Pertahanan \\ Indonesia, Bogor, 16810, Indonesia
}

Received 16 February 2021/Revised 12 July 2021/Accepted 25 July 2021/Published 17 August 2021

\begin{abstract}
There are still many people in Jakarta who throw their garbage into the river, resulting Jakarta city never being absent from the problems of river water pollution and flooding. Pesanggrahan River and Grogol River are some of the big river surrounded by high popullation area. All waste originating from the Pesanggrahan River and the Grogol River is dumped into the Bantar Gebang Landfill. This study aimed to reduce waste entering landfills are by making use of waste that still has economic value. The method used in decision making from various alternatives of the river waste utilization are utility theory and compromise programming. It takes planning to find out the composition and generation of solid waste from those rivers and to determine the potential use of river waste and the action to minimize and handle the river waste. Utilization of river waste that can be applied based on the composition of most waste is open windrow composting and plastic shredding. It is important to concern about river waste since Indonesia has various polluted river, especially by solid waste. By implementing a good river waste utilization, the waste that enters the landfill will be reduced and in line with reduced pollution to the aquatic environment.
\end{abstract}

Keywords: Solid waste; Water; Generation; Composition; Utilization

\section{Introduction}

As the human population increases, the amount of solid waste produced will also increase. The population density on the riverbanks will indirectly increase the generation of waste disposed into the river and the load of river pollutants (Arsyandi, 2019). Many people have an understanding that throwing solid waste into the river can solve their waste problem because the water flow will take their waste away (Yusfi \& Damanhuri, 2012). The discharge of solid waste can be transported through various pathways, including dumpsites, lack of goodwaste management, stream flow, tourist littering behavior, and marine activities such as fishing, aquaculture, shipping and dumping (GESAMP, 2016).

*Corresponding author.

Email address : mega.tiarasari1986@gmail.com (Mega Mutiara Sari) 
Rahajeng Hasna Safira et al. / Geosfera Indonesia 6 (2), 2021, 157-172

The Jakarta environmental office noted that there were around $150-250 \mathrm{~kg} /$ day waste generationfor one river under normal conditions (UPK Badan Air, 2019). Meanwhile, Jakarta itself is passed by approximately 19 large rivers that flow from downstream to the coast of Jakarta.Almost all the solid waste from Jakarta rivers disposed of at the Bantar Gebang landfill along with the land waste. River waste contributed $1232.02 \mathrm{~m}^{3}$ (UPK Badan Air, 2019) out of a total of 7702.07 tons of waste that goes to Bantar Gebang landfill every day (DLH DKI Jakarta, 2020). As a result, the waste from the river will increase the amount of waste generated in the Bantar Gebang landfill. This should be our concern because the service life of Bantar Gebang landfill is no more than 5 years left. If the waste in the river is left without proper management, it will flow into the estuary and can be carried to the sea. This can lead to a bigger problem namely marine pollution. Lack of good waste management in coastal countries has contributed $1.7 \%$ - $4.6 \%$ of plastic waste to the sea (Jambeck, 2015). The presence of marine debris not only affects the aesthetic value of the environment, but also has the potential to disrupt maritime activities such as aquaculture and fisheries (UNEP, 2014) and posing a threat to marine wildlife and human health (Purba et al., 2019). In addition, waste disposal along water bodies can inhibits river flow which can result in flooding (Karuniastuti, 2014).

Waste Management Law (2008) prioritize waste minimization from the source, utilization of waste that is still useful, and minimizing waste entering the landfill. This has prompted the need for further waste management regarding the waste generation generated in the areas along the Pesanggrahan River and the Grogol River from various activities along the river flow. The Pesanggrahan River and the Grogol River are rivers that pass through the West Jakarta area. West Jakarta itself is the area with the highest population density in DKI Jakarta Province with a total of 18,996 people $/ \mathrm{km}^{2}$ in 2015 and has a population projection for 2019 of 2,482,800 people (BPS, 2015). One of the causes of the high level of pollution in the Pesanggrahan River is the result of the decomposition of solid waste entering the river (Noerfitriyani, 2018). In addition, the Grogol River is one of the rivers that is of concern to the World Bank Group in its study because the Grogol River is one of the rivers that contributes quite a lot of garbage to the sea (World Bank Group, 2018).

In carrying out the river waste utilization, facilities and operational techniques for river waste management are needed that can support the utilization process properly. There is previous research that discusses the design of waste container for riverbanks as an effort to reduce waste dumped into the river. Some researchers focused on domestic waste from household that has a high probability of dumping its garbage into the river. There are some studies that are limited by the location of waste sampling and only use waste characteristic 
data as the basis for selecting the processing methods. Therefore, this research intends to carry out direct measurements of the waste in the river and to assess objectively and subjectively in the choice of waste processing methods.From this planning, it is hoped that it can reduce waste entering the Bantar Gebang landfill and reduce the negative impact by handling waste from its source on a community-based basis around the river.

\section{Methods}

The method used in measuring waste generation and density was direct measurement which refers to SNI 19-3694-1994 on the method of collecting and measuring samples of municipal solid waste generation and composition and was equipped with load count analysis. Measurement of generation using the load count analysis method is to measure the amount (weight or volume) of waste entering the transfer station (Damanhuri \& Padmi, 2016).

Determination of alternative solutions is done by using the multi-objective decision making (MODM) method with utility theory and compromise programming.Utility theory and compromise programming function to determine parameters based on the best and worst values. The best result is the alternative which has the best parameter with the highest value. In determining the best processing alternative, an assessment is carried out based on parameters that affect the processing process in terms of labor, finance, and the quality of the processing results. Each alternative will have different preferences and ratings for each parameter. The assessment for each parameter was obtained from the calculation results and also from literature studies. Verbal assessment in this method needs to transform the objective function value into a degree of non-dimensional objective performance on a scale (eg, 0-1). The weighting of this method is made according to the relative importance of the objectives. After doing it non-dimensionally, the next step is to calculate the total utility value. The highest utility value is the best result (Fishburn, 1970).

River debris or riverwastecould be a strong material that is troublesome to break down, manufactured, or handled which is dumped, arranged of, or cleared out within the marine and coastal environment. Riverwaste consists of things made or utilized by people and intentionally dumped into the ocean or waterways, or cleared out lying on the shoreline or coast; washed by implication to the ocean by waterways, channels, runoff or wind; or incidentally misplaced, counting things misplaced at ocean (World Bank Group, 2018).

Primary data collection in the form of waste generation and waste composition was carried out in November 2019 in the Pesanggrahan River and December 2019 in the Grogol River. Based on data from the Indonesian Meteorological and Climatological Agency, the 
beginning of the rainy season in Western Indonesia occurs around October to December and peaks in January and February. Waste samples taken are garbage collected in floating cube for 24 hours and are taken in the morning in the range of 08.00-10.00 AM before the waste transported to a special transfer station for river waste. Sampling of river waste was carried out once for each location of the floating cube which refers to the World Bank Group study about Indonesia's Marine Garbage Hot Spot. Floating cube is a device used to hold waste carried away by rivers. Hence, there will be a lot of solid waste trapped on the floating cube.

There are 5 sampling locations on the Pesanggrahan River and 1 sampling location on the Grogol River were carried out on the part of the river that has a floa ting cube as shown in Figures 1 and 2.

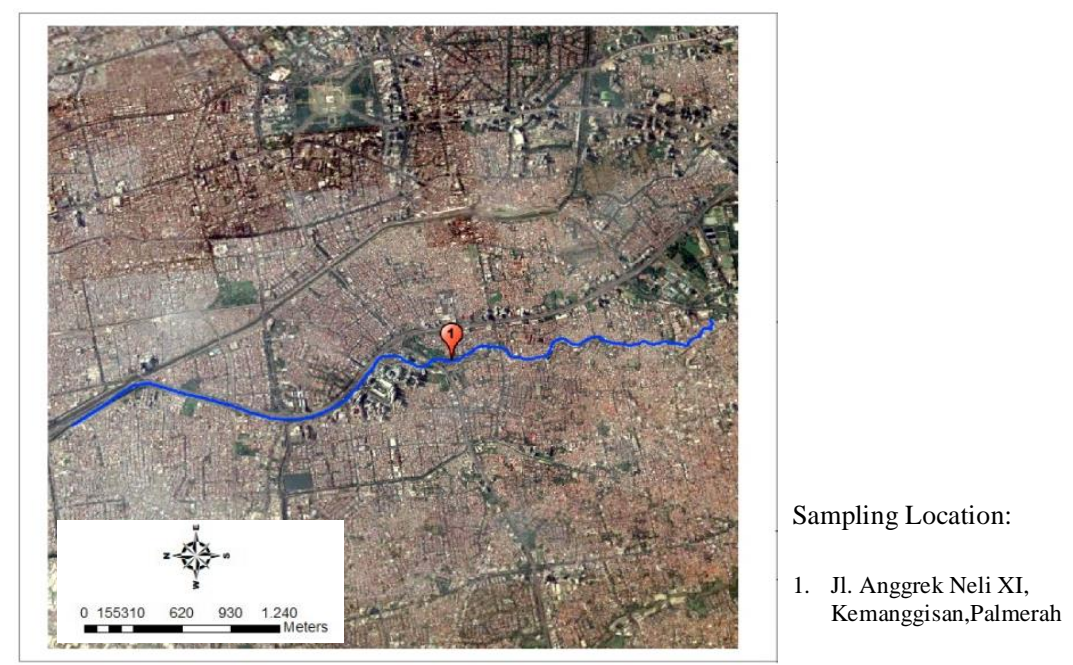

Source: (ESRI, 2016; Google, 2020)

Figure 1. Sampling Point for Grogol River Waste

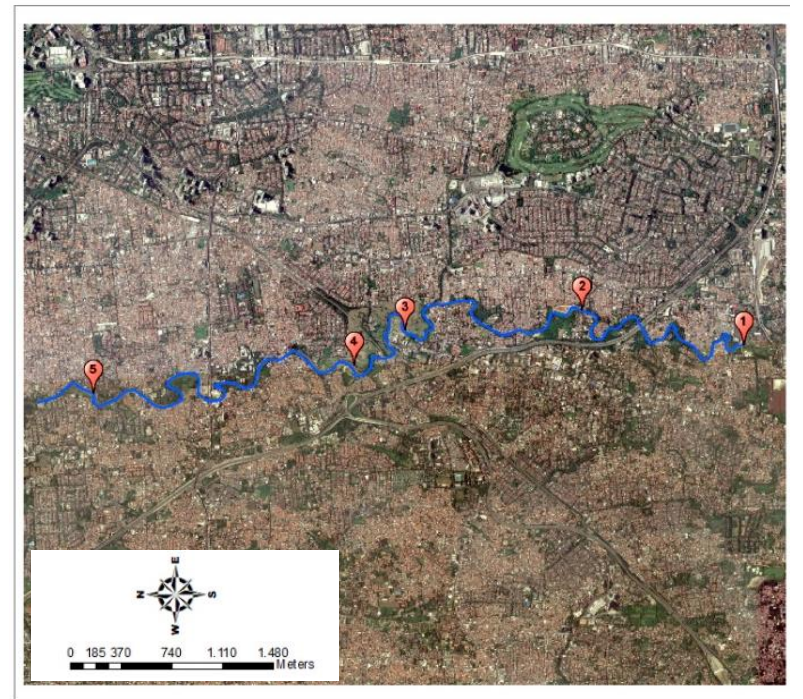

Sampling Location:

Jl. CempakaPondok Pinang, Kebayoran Lama Jl. Deplu Raya, Pondok Pinang, Kebayoran Lama

Tanah Kusir Veteran Cemetery Jl. Inspeksi, Pesanggrahan Jl. Persatuan, Grogol Selatan

Source: (ESRI, 2016; Google, 2020)

Figure 2. Sampling Point for Pesanggrahan River Waste 


\section{Results and Discussion}

\subsection{Waste Generation}

River waste generation data were collected at locations in the Pesanggrahan River and one location at the Grogol River. The location division is based on the location of the insulating cube or floating cube that has been used by the UPK Badan Air to filter waste in the river. UPK Badan Air is the party responsible for cleaning up the aquatic environment in the Jakarta area. The results of the measurement of waste generation in both rivers are shown in units of weight and volume. The average of waste generation from 5 locations on the Pesanggrahan River was $50.77 \mathrm{~kg} /$ day with a maximum waste generation of $271.40 \mathrm{~kg} / \mathrm{day}$, while the average of waste generation at the study location on the Grogol River was 34.64 $\mathrm{kg} /$ day with the maximum generation can reach $188.82 \mathrm{~kg} /$ day. The largest volume of waste generation occurred in the Pesanggrahan River is $12 \mathrm{~m}^{3} /$ day. Whereas the smallest volume occurs in the Grogol River at $0.1 \mathrm{~m}^{3} /$ day. Both rivers have an average generation volume of $2.45 \mathrm{~m}^{3} /$ day. An increase in the volume of waste in rivers can be caused by increasing river water levels due to rain or flooding. In addition, the high volume of waste can be caused by the presence of garbage with a very large size so that the size of the waste volume will also increasing.

From the measurement results of waste generation and analysis of secondary data on waste generation for one month, the highest waste generation always occurs on Saturdays and Sundays, while the lowest for waste generation occurs on Wednesdays. This is because many people spend their time at home on weekend so that activities in the house will increase as well as the amount of waste generated. Figure 3 and Figure 4 show the lowest, average, and highest waste generation from each location during the study period.

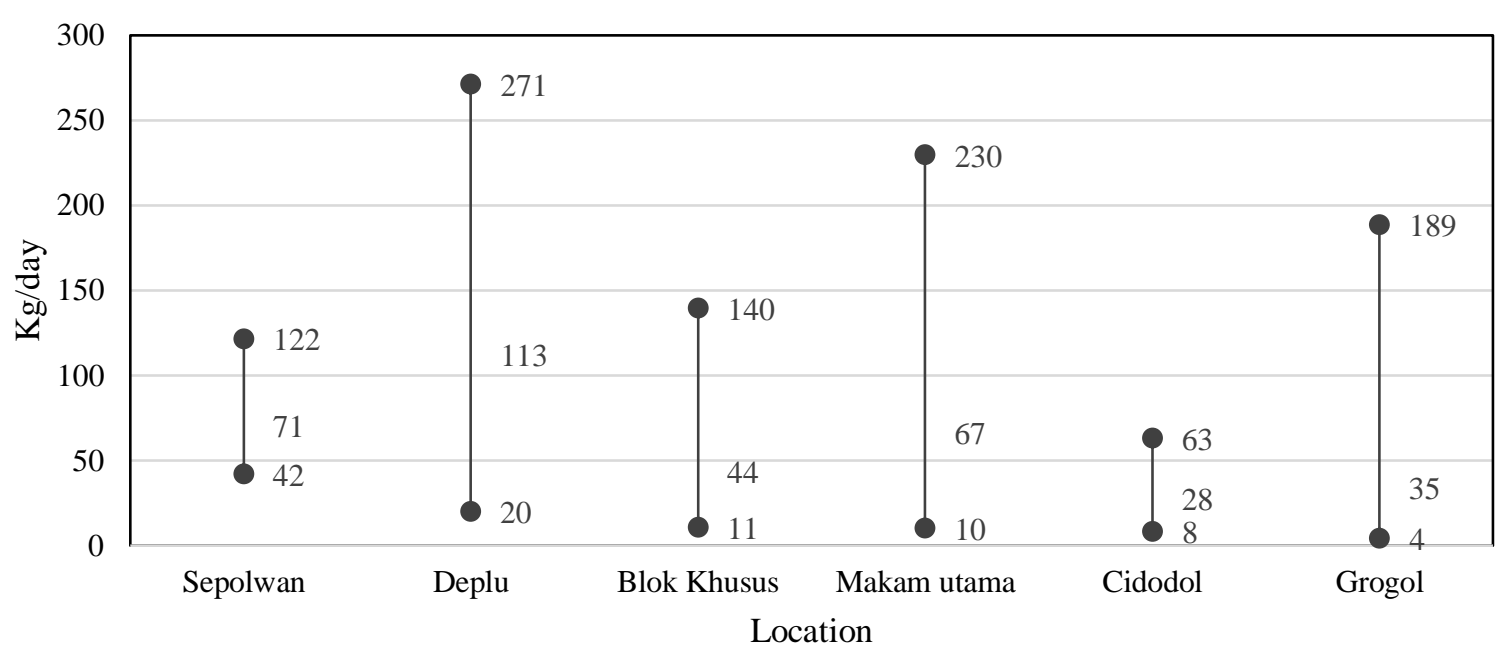

Figure 3. Waste Generation in kg/day 
Rahajeng Hasna Safira et al. / Geosfera Indonesia 6 (2), 2021, 157-172

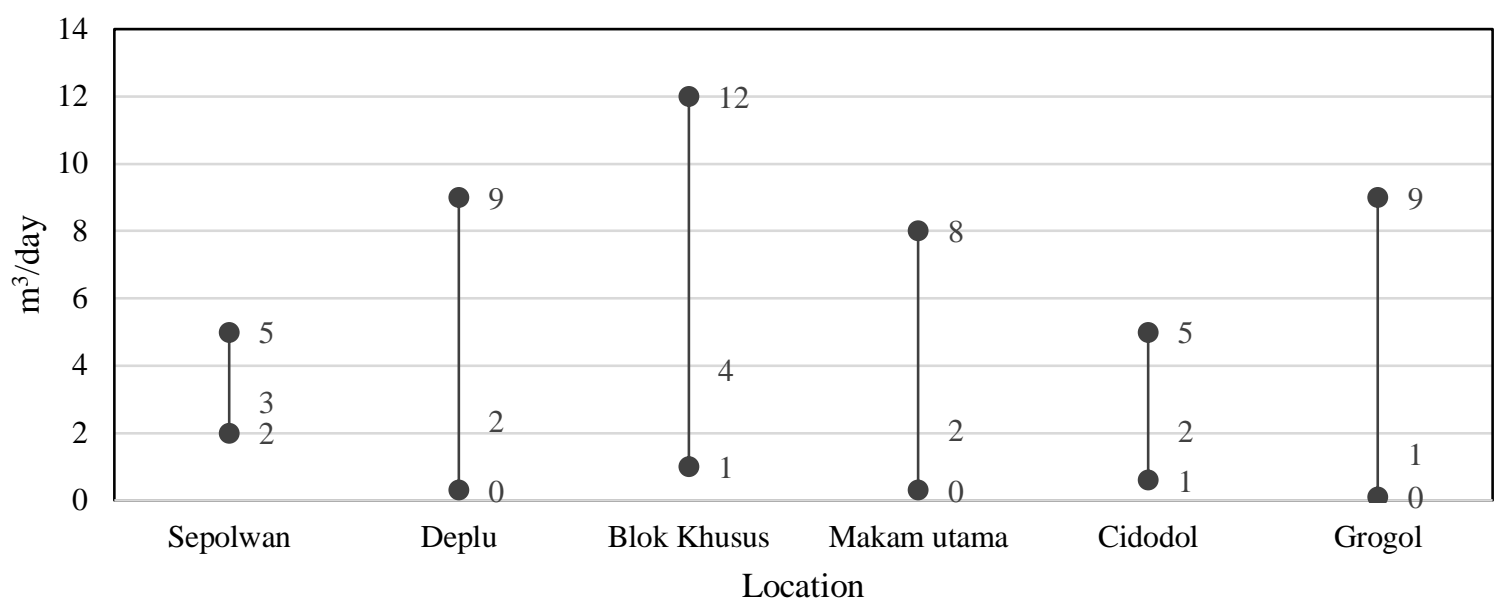

Figure 4. Waste Generation in $\mathrm{m}^{3} /$ day

\subsection{Waste Composition}

The categories of waste in this study are divided into food, wood, twig, and garden waste, paper and cardboard, textiles, rubber and leather, plastic, metal, glass, and others or inert. The waste categories with the highest percentage in the Pesanggrahan and Grogol Rivers are plastic and wood or twig waste. This is because there are still many people who still use single-use plastic as their own trash wrapper. In addition, around Pesanggrahan and Grogol Rivers, there are a lot of slums area less than 50 meters from the riverbank. The large amount of plastic waste found in rivers proves that Indonesia is the country with the second highest plastic use in the world (Jambeck, 2015). Plastics that are often found are categorized into various types such as plastic bags, PET bottles, straws, plastic product packaging, and various other types of plastic. The second highest composition of waste is wood and garden waste. There are still many riverbanks in Jakarta that have not been founded properly so the water bodies directly intersect with the land along the river flow. This made it easier for many plants on the riverbank to fall and eventually get carried away by the river currents until they got stuck in the floating cube. Table 1 shows the average percentage composition of River Waste in Pesanggrahan River and Grogol River. Understanding the role of the source and composition of the waste will be important for designing an effective mitigation strategy (Purba et al., 2019). 
Rahajeng Hasna Safira et al. / Geosfera Indonesia 6 (2), 2021, 157-172

Table 1 . The average percentage composition of river waste

\begin{tabular}{cc}
\hline Waste category & Percentage (\%) \\
\hline Plastic & 43.54 \\
Food waste & 1.00 \\
Wood, twig, garden waste & 43.90 \\
Paper & 1.45 \\
Metal & 1.19 \\
Cloth and textiles & 2.91 \\
Rubber and leather & 2.93 \\
Glass & 1.28 \\
Others & 1.81 \\
Total & 100 \\
\hline
\end{tabular}

The high category of wood and twig waste or biodegradable waste of $43.90 \%$ could be a potential for waste processing through household scale composting activities. Another dominant waste category is plastic at $43.54 \%$. The large amount of plastic waste found in rivers proves that Indonesia is a country with the second highest plastic use in the world (Jambeck, 2015). Research by Purba et al. (2019) on several beaches and bays in Indonesia showing that the type of waste that is most commonly found is plastic from micro to macro sizes. Table 2 shows the comparison of the composition of marine waste or waste generating from river in other countries. The percentage composition of plastic waste and organic waste in Indonesian waters is higher than Malaysia and India. However, in 2019 Indonesia showed an effort to understand more aspects of the problem of marine plastic waste compared to other Southeast Asian countries (Lyons, Su, \& Neo, 2019).

Table 2. Comparison of the composition of marine waste or waste generating from river in other countries

\begin{tabular}{cccc}
\hline Waste category & $\begin{array}{c}\text { Indonesia } \\
(\mathbf{\%})\end{array}$ & $\begin{array}{c}\text { Malaysia } \\
(\mathbf{\%})\end{array}$ & $\begin{array}{c}\text { India } \\
(\mathbf{\%})\end{array}$ \\
\hline Plastic & 44 & 43 & 41 \\
Food waste & 1 & 1 & 0 \\
Wood, twig, garden waste & 44 & 0 & 8 \\
Paper & 1 & 48 & 0 \\
Metal & 1 & 1 & 10 \\
Cloth and textiles & 3 & 0 & 18 \\
Rubber and leather & 3 & 0 & 9 \\
Glass & 1 & 0 & 8 \\
Others & 2 & 7 & 7 \\
Total & 100 & 100 & 100 \\
\hline
\end{tabular}

Source: (Khairunnisa et al., 2012) \& (Selvam et al., 2020). 
Processing plastic waste can be done by recycling or reusing waste with the $3 \mathrm{R}$ concept such as a waste bank. With the management and processing of waste in the community, it is hoped that it can reduce the amount of waste generation that enters the river and Bantar Gebang landfill. In addition, waste management and processing in the community can also increase the income of the people around the riverbank.

\subsection{Waste Utilization}

The purpose of waste utilization is to reduce the volume of waste and the pollutant power of waste in the environment. The application of waste utilization activities can bring benefits that are both direct (tangible) and indirect (intangible). Tangible benefits can be in the form of income from recycled materials or the sale of compost products and the use of compost liquid residues from processing as fertilizer. Meanwhile, benefits that cannot be valued by money (intangible) include reducing the degree of pollution and preserving water resources as well as social benefits in the form of decreasing the degree of conflict caused by waste pollution. By carrying out waste utilization, one of the targets of the 17 Sustainable Development Goals can be realized, i.e. substantially reduce waste generation through prevention, reduction, recycling and reuse (United Nation ESCAP, 2015).The process of utilizing waste generally requires engineering in forms such as grouping, purification, mixing, and processing to be able to obtain materials that are suitable for the function of these recycled materials (Tchobanoglous \& Kreith, 2002).

Based on the measurement results of the composition of the waste that trapped in floating cube, it was found that the largest composition was wood and twig waste or biodegradable waste by $43.90 \%$ and plastic waste by $43.54 \%$. Therefore, processing for river waste will be focused on processing organic waste in the form of wood, twigs, and garden waste as well as inorganic waste in the form of plastic waste.

One of the things that distinguishes river waste from land waste is the parameter of water content. The water content of river waste is in the range of $85 \%-95 \%$ for organic waste and 50\%-70\% for inorganic waste (Yusfi \& Damanhuri, 2012). The highwater content in river waste is caused by wet environmental conditions. This condition will make it difficult for further processing, both composting and material recycling. Therefore, a drying or heating process is needed before the waste is processed.

\subsubsection{Composting}

The purpose of composting is to convert biodegradable organic material into biologically stable material, thereby reducing its volume or mass. This natural process breaks down organic matter into humus and mineral matter. The composting process itself can be 
done through an aerobic or anaerobic process. There are various methods that can be used to process organic waste in the form of wood, twigs, and garden waste. Organic waste originating from rivers will have a high moisture content, so it is necessary to have a drying process prior to composting. The quality of the biodegradable waste and certain biological and physical parameters has a major influence on the quality of the compost and on the occurrence of operational problems with the composting facility.It is important to understand the physical, biological and chemical processes involved in the decomposition of biodegradable waste (United Nation ESCAP, 2012). Although river organic waste has more diverse content and tends to be mixed, the end result of the composting process without proper sorting is not significantly different from the composting process with initial sorting and has good quality (Sahwan, 2010).To determine what method is best applied for river waste processing, a decision is made using utility theory and compromise programing methods based on the feasibility category of a waste treatment. The assessment is carried out based on several criteria that are important to be achieved in composting activities. The components for each category of each alternative are obtained from the results of calculations and literature studies.Following are the results of an assessment of 4 composting methods. Table 3 shows the qualitative and quantitative assessment for each criteria.

Table 3. Preference and assessment of composting methods for river organic waste

\begin{tabular}{|c|c|c|c|c|}
\hline Criteria & Bricks Stack & $\begin{array}{c}\text { Open } \\
\text { Windrow }\end{array}$ & $\begin{array}{c}\text { Drum } \\
\text { Composter } \\
\end{array}$ & $\begin{array}{c}\text { Takakura } \\
\text { Stack }\end{array}$ \\
\hline Aesthetics & Organized & Unorganized & $\begin{array}{c}\text { Quite } \\
\text { organized }\end{array}$ & $\begin{array}{c}\text { Quite } \\
\text { organized }\end{array}$ \\
\hline Land requirements & $333 \mathrm{~m}^{2}$ & $91.3 \mathrm{~m}^{2}$ & $544.32 \mathrm{~m}^{2}$ & $1763.42 \mathrm{~m}^{2}$ \\
\hline Ease of operation & Moderate & Easy & Hard & Hard \\
\hline Ease of development & Hard & Moderate & Easy & Easy \\
\hline $\begin{array}{l}\text { Investment \& } \\
\text { operational prices } \\
\text { (Wahyono \& Sahwan, } \\
\text { 2010) }\end{array}$ & $\begin{array}{c}\text { IDR } \\
75,386,421\end{array}$ & $\begin{array}{c}\text { IDR } \\
65,786,421\end{array}$ & $\begin{array}{c}\text { IDR } \\
667,265,921\end{array}$ & $\begin{array}{c}\text { IDR } \\
416,657,921\end{array}$ \\
\hline $\begin{array}{l}\text { Water content (Ratna, } \\
\text { 2017) }\end{array}$ & $58.30 \%$ & $35.24 \%$ & $34.28 \%$ & $60 \%$ \\
\hline C organic & 12.33 & $11.15 \%$ & $4.04 \%$ & $29.29 \%$ \\
\hline $\mathrm{N}$ total & $1.50 \%$ & $0.55 \%$ & $0.27 \%$ & $1.92 \%$ \\
\hline $\begin{array}{l}\text { C/N (Ayumi, Lutfi \& } \\
\text { Nugroho, 2017) }\end{array}$ & 15.33 & 20 & 15 & 15.22 \\
\hline Phosphor & $0.34 \%$ & $0.22 \%$ & $0.25 \%$ & $0.12 \%$ \\
\hline Potassium & $1.93 \%$ & $0.51 \%$ & $0.06 \%$ & $1.43 \%$ \\
\hline $\mathrm{pH}$ & 6.9 & 7.4 & 7.4 & 7.4 \\
\hline
\end{tabular}


Table 4 shows the qualitative and quantitative assessment components converted to a number scale (1-3) with the largest number being the best and the smallest number being the worst.

Table 4. Transforming verbal assessments into numbers and determining the best and worst scores for each preference

\begin{tabular}{lcccccc}
\hline \multicolumn{1}{c}{ Criteria } & $\begin{array}{c}\text { Bricks } \\
\text { Stack }\end{array}$ & $\begin{array}{c}\text { Open } \\
\text { Windrow }\end{array}$ & $\begin{array}{c}\text { Drum } \\
\text { Composter }\end{array}$ & $\begin{array}{c}\text { Takakura } \\
\text { Stack }\end{array}$ & Best & Worst \\
\hline Aesthetics & 3 & 1 & 2 & 2 & 3 & 1 \\
Land requirements & 2 & 3 & 1 & 1 & 3 & 1 \\
Ease of operation & 2 & 3 & 1 & 1 & 3 & 1 \\
Ease of & 1 & 2 & 3 & 2 & 3 & 1 \\
development & & 3 & 1 & 2 & 3 & 1 \\
Investment \& & 3 & 3 & 3 & 1 & 3 & 1 \\
operational prices & 1 & 3 & 1 & 2 & 3 & 1 \\
Water content & 3 & 2 & 1 & 3 & 3 & 1 \\
C organic & 3 & 1 & 2 & 3 & 3 & 1 \\
N total & 3 & 2 & 2 & 1 & 3 & 1 \\
C/N & 3 & 2 & 1 & 2 & 3 & 1 \\
Phosphor & 3 & 3 & 3 & 3 & 3 & 2 \\
Potassium & 2 & & & & & \\
pH & & & & & &
\end{tabular}

Table 5 shows the conversion of ratings on a $0-1$ scale, the determination of the weighting, and the calculation of the weighting standard. In Table 5 also shows the results of the calculation of utility theory for each alternative where the alternative with the highest utility theory value is the best to be chosen.

Table 5. Conversion of ratings on a scale of $0-1$ and utility theory ratings

\begin{tabular}{|c|c|c|c|c|c|c|}
\hline Criteria & $\begin{array}{l}\text { Bricks } \\
\text { Stack } \\
\end{array}$ & $\begin{array}{c}\text { Open } \\
\text { Windrow } \\
\end{array}$ & $\begin{array}{c}\text { Drum } \\
\text { Composter }\end{array}$ & $\begin{array}{c}\text { Takakura } \\
\text { Stack } \\
\end{array}$ & Weight & $\begin{array}{l}\text { Weighting } \\
\text { Standards } \\
\end{array}$ \\
\hline Aesthetics & 1 & 0 & 0.5 & 0.5 & 1 & 0.03 \\
\hline Land requirements & 0.5 & 1 & 0 & 0 & 3 & 0.10 \\
\hline Ease of operation & 0.5 & 1 & 0 & 0 & 2 & 0.06 \\
\hline Ease of development & 0 & 0.5 & 1 & 0.5 & 1 & 0.03 \\
\hline $\begin{array}{l}\text { Investment \& } \\
\text { operational prices }\end{array}$ & 1 & 1 & 0 & 0.5 & 3 & 0.10 \\
\hline Water content & 0 & 1 & 1 & 0 & 3 & 0.10 \\
\hline C organic & 1 & 1 & 0 & 0.5 & 3 & 0.10 \\
\hline $\mathrm{N}$ total & 1 & 0.5 & 0 & 1 & 3 & 0.10 \\
\hline $\mathrm{C} / \mathrm{N}$ & 1 & 0 & 0.5 & 1 & 3 & 0.10 \\
\hline Phosphor & 1 & 0.5 & 0.5 & 0 & 3 & 0.10 \\
\hline Potassium & 1 & 0.5 & 0 & 0.5 & 3 & 0.10 \\
\hline $\mathrm{pH}$ & 0 & 1 & 1 & 1 & 3 & 0.10 \\
\hline \multicolumn{5}{|c|}{ Total } & 31 & 1 \\
\hline Utility value & 0.69 & 0.71 & 0.34 & 0.47 & & \\
\hline Ranking & 2 & 1 & 4 & 3 & & \\
\hline
\end{tabular}


After obtaining the best alternative through the calculation of utility theory, then Table 6 shows the calculation of the value of compromise programming by considering the compromise factor where the alternative with the highest value indicator is the best to be chosen.

Table 6. The assessment uses compromise programming theory

\begin{tabular}{lcccc}
\hline Compromise program $\mathbf{C = 2}$ & & & & \\
\hline Distance & 0.27 & 0.21 & 0.60 & 0.44 \\
Indicator value & 0.73 & 0.79 & 0.40 & 3.00 \\
Ranking & $\mathbf{2}$ & $\mathbf{1}$ & $\mathbf{4}$ & $\mathbf{3}$ \\
\hline
\end{tabular}

From the results of the assessment and weighting using the utility theory and compromise programming methods, it was found that the alternative with the highest ranking was the open windrow by using bamboo aerators. This indicates that bamboo aerators are a better alternative for processing river organic waste. By analyzing the economic benefits for bamboo aerators, it is found that the annual operational costs are IDR 34,492,624 and annual sales of IDR 42,705,000. From the estimation of these two costs, an estimate of the economic benefit that can be valued by money (tangible) from the bamboo aerator is IDR 8,212,375. Meanwhile, the indirect (intangible) benefits that can be obtained are increased soil fertility, increased soil nutrients, reduced soil contamination by garbage, and other benefits.

\subsubsection{Plastic Recycling}

In this study, it was found that the type of inorganic waste that is mostly found in rivers is plastic waste. Conventional plastics are not biodegradable and can survive in the environment for hundreds of years, but due to hydrodynamics and exposure to light, plastics can fragment into tiny particles that are harmful to aquatic organisms as well as humans (Galgani et al., 2019).As a consequence of the accumulation and fragmentation of plastic in the oceans, there will be an increased ecotoxicological risk (Hermabessiere et al., 2017).That is why plastic waste utilization is needed to prevent plastic fragmentation from occurring in the water environment. Plastic recycling is a series of processes carried out to make plastic waste into secondary materials to be used as raw materials for new products (Tarverdi, 2010). The processing of plastic waste itself can be done by chopping the plastic to a small size and then packing and selling it to collectors or industry. Besides that, you can also melt the plastic waste and print it in the form of plastic pellets / pellets as the base material for new products. The plastic collected can be in the form of plastic household utensils, product packaging, plastic bags, and various other types of plastic. Plastic waste originating from rivers will tend to be dirtier due to silt and plastic in wet conditions, so it is necessary to consider drying and cleaning efforts before plastic waste can be processed.To determine what 
method is best applied for river waste processing, a decision is made using utility theory and compromise programing methods based on the feasibility category of a waste treatment. The assessment is carried out based on several criteria that are important to be achieved in plastic recycling activities. The components for each category of each alternative are obtained from the results of calculations and literature studies.Following are the results of the assessment of 2 methods of plastic recycling. Table 7 shows the qualitative and quantitative assessment for each criteria.

Table 7. Preference and assessment of river plastic waste processing

\begin{tabular}{|c|c|c|}
\hline Criteria & Plastic Shredding & $\begin{array}{c}\text { Melting and } \\
\text { Forming of Plastic } \\
\text { Pellets } \\
\end{array}$ \\
\hline Workload & Low & Moderate \\
\hline Investment \& operational prices & IDR $83,022,857$ & IDR $260,484,668$ \\
\hline Ease of operation & Easy & Hard \\
\hline Ability to reduce waste & $100 \%$ & $74.72 \%$ \\
\hline Sales per year & IDR $79,068,246$ & IDR $84,339,616$ \\
\hline
\end{tabular}

Table 8 shows the qualitative and quantitative assessment components converted to a number scale (1-3) with the largest number being the best and the smallest number being the worst.

Table 8. Transforming verbal assessments into numbers and determining the best and worst scores for each preference

\begin{tabular}{lcccc}
\hline \multicolumn{1}{c}{ Criteria } & $\begin{array}{c}\text { Plastic } \\
\text { Shredding }\end{array}$ & $\begin{array}{c}\text { Melting and } \\
\text { Forming of } \\
\text { Plastic Pellets }\end{array}$ & Best & Worst \\
\hline Workload & 2 & 3 & 3 & 2 \\
Investment \& operational & IDR & IDR & IDR & IDR \\
prices & $83,022,857.85$ & $260,484,668.33$ & $83,022,857.85$ & $260,484,668.33$ \\
Ease of operation & 3 & 1 & 3 & 1 \\
Ability to reduce waste & $100 \%$ & $74.72 \%$ & $100 \%$ & $74.72 \%$ \\
Sales per year & IDR & IDR & IDR & IDR \\
& $79,068,246.00$ & $84,339,616.00$ & $79,068,246.00$ & $84,339,616.00$ \\
\hline
\end{tabular}

Table 9 shows the conversion of ratings on a $0-1$ scale, the determination of the weighting, and the calculation of the weighting standard. In Table 5 also shows the results of the calculation of utility theory for each alternative where the alternative with the highest utility theory value is the best to be chosen. 
Rahajeng Hasna Safira et al. / Geosfera Indonesia 6 (2), 2021, 157-172

Table 9. Conversion of ratings on a scale of $0-1$ and utility theory ratings

\begin{tabular}{lcccc}
\hline \multicolumn{1}{c}{ Criteria } & $\begin{array}{c}\text { Plastic } \\
\text { Shredding }\end{array}$ & $\begin{array}{c}\text { Melting and } \\
\text { Forming of Plastic } \\
\text { Pellets }\end{array}$ & Weight & $\begin{array}{c}\text { Weighting } \\
\text { Standards }\end{array}$ \\
\hline Workload & 0 & 1 & 2 & 0.15 \\
$\begin{array}{l}\text { Investment \& operational } \\
\text { prices }\end{array}$ & 1 & 0 & 3 & 0.23 \\
Ease of operation & 1 & 0 & 3 & 0.23 \\
Ability to reduce waste & 1 & 0 & 2 & 0.15 \\
Sales per year & 0 & 1 & 3 & 0.23 \\
\hline & Total & & 13 & 1 \\
& Utility value & & 0.615 & 0.385 \\
& Ranking & & 1 & 2 \\
\hline
\end{tabular}

After obtaining the best alternative through the calculation of utility theory, then Table 10 shows the calculation of the value of compromise programming by considering the compromise factor where the alternative with the highest value indicator is the best to be chosen.

Table 10. The assessment uses compromise programming theory

\begin{tabular}{lcc}
\hline Compromise program $\mathrm{C}=2$ & & \\
\hline Distance & 0.385 & 0.615 \\
Indicator value & 0.615 & 0.385 \\
Ranking & $\mathbf{1}$ & $\mathbf{2}$ \\
\hline
\end{tabular}

From the results of the assessment and weighting using the utility theory and compromise programming methods, it is found that the alternative with the highest ranking is plastic shredding. This indicates that shredding is a better alternative to be applied to river plastic waste processing. By analyzing the economic benefits for shredding, it is found that the annual operational costs are IDR 41,311,830 and annual sales of IDR 79,068,246. From the estimation of the two costs, the estimated tangible economic benefit from shredding is IDR 37,756,415. Meanwhile, the benefits that cannot be valued by money (intangible) include reducing the degree of pollution, preserving water resources from plastic waste, and reducing plastic waste entering the sea. The social benefits that can be obtained are as a reference for the community in forming a habit of processing plastic waste.

Waste processing by composting and plastic shredding will be carried out in the vicinity of the waste source, which in this case is a floating cube. Another alternative that can be used is to utilize public open spaces where partners between the local government and the community occur. One of the public open spaces that is widely available around the study site 
and which can be utilized is the Child Friendly Open Public Space. By processing waste in public open spaces, educational efforts regarding waste management both materially and practically can be conveyed properly to the public.

\section{Conclusion}

All the garbage originating from the Pesanggrahan River and Grogrol River has entered the Bantar Gebang Landfill. Whereas, there are several types of river waste that still have economic value. By making waste utilization efforts, pollution in the aquatic environment can be reduced, especially microplastic pollution. River waste utilization can be a unique thing where so far, most of the waste utilization activities use waste from household or land. In addition, this effort can also be a good example for the public and can help maintain the sustainability of the circular economy. The next idea of the study required studies on the community to determine the level of knowledge and willingness of the community in utilizing river waste and further study by carrying out projections of river solid waste data to determine the service period. The future work that needs to be done is to improve river waste management by working with waste banks as a place to sort and process waste originating from rivers.

\section{Conflict of Interest}

The authors declare no conflict of interest.

\section{Acknowledgements}

The authors would like to thank the Japan Society for The Promotion Science and Indonesia Directorate General of Research, Technology and Higher Education (JSPS/DGRSTHE), a Bilateral Joint Research Projects 2019-2022 between Universitas Pertamina and Toyohashi University of Technology which has become a forum and facilitator in the implementation of this research. Special thanks also extended to UPK Badan Air who has given the permission to take samples in their working area.

\section{References}

Arsyandi, M. Y. (2019). Perencanaan Sistem Pewadahan dan Pengumpulan Sampah Rumah Tangga di Bantaran Sungai Cikapundung Kota Bandung. Jurnal Serambi Engineering (JSE), 4(2). https://doi.org/10.32672/jse.v4i2.1464.

Ayumi, I. d., Lutfi, M., \& Nugroho, W. A. (2017). Efektivitas Tipe Pengomposan (Konvensional, Aerasi, dan Rak Segitiga) terhadap sifat fisik dan kimia kompos dari sludge biogas dan Serbuk Gergaji. Jurnal Keteknikan Pertanian Tropis dan Biosistem, 5(3), 265-272. 
BPS. (2015). Profil Kependudukan Hasil SUPAS 2015 Provinsi DKI Jakarta. Jakarta: Badan Pusat Statistik (BPS).

Damanhuri, E., \& Padmi, T. (2016). Pengelolaan Sampah Terpadu. Bandung: ITB.

DLH DKI Jakarta. (2020). Data-data TPST Bantar Gebang. Retrieved from Portal Resmi Pengelolaan Sampah Terpadu Dinas Lingkungan Hidup Provinsi DKI Jakarta: https://upst.dlh.jakarta.go.id/tpst/data.

ESRI (2016). ArcGIS Basemap. Retrieved from https://www.esri.com/en-us/home.

Fishburn, P. C. (1970). Utility theory and decision making. New York: John Wiley \& Sons, inc.

Galgani, L., Beiras, R., Galgani, F., Panti, C., et al. (2019). Impacts of Marine Litter. Frontier in Marine Science, 4(11) https://doi.org/10.3389/fmars.2019.00208.

GESAMP, (2016). Sources, fate and effects of microplastics in the marine environment: a global assessment. London : International Maritime Organization.

Google (2020). Google Map. Retrieved from https://www.google.co.id/maps.

Hermabessiere, L., Dehaut, A., Paul-Pont, I., Lacroix, C., Jezequel, R., Soudant, P., et al. (2017). Occurrence and effects of plastic additives on marine environments and organisms: a review. Chemosphere, 182(1), 781-793. https://doi.org/10.1016/j.chemosphere.2017.05.096.

Jambeck, J. R., Geyer, R., Wilcox, C., Siegler, T. R., Perryman, M., Andrady, A., ... Law, K. L. (2015). Plastic waste inputs from land into the ocean. Science, 347(6223), 768771. https://doi.org/10.1126/science.1260352.

Karuniastuti, N. (2014). Teknologi biopori untuk mengurangi banjir dan tumpukan sampah organik . Swara Patra, 4(2), 60-68.

Khairunnisa, A. K., Fauziah, S. H., \& Agamuthu, P. (2012). Marine debris composition and abundance: A case study of selected beaches in Port Dickson, Malaysia. Aquatic Ecosystem Health \& Management, 15(3), 279-286. https://doi.org/10.1080/14634988.2012.703096.

Lyons, Y., Su, T. L., \& Neo, M. L. (2019). A review of research on marine plastics in Southeast Asia: Who does what?. London: UK Science \& Innovation Network.

Noerfitriyani, E. (2018). Impact of Leachate Discharge from Cipayung Landfill on Water Quality of Pesanggrahan River, Indonesia. IOP Conference Series: Earth and Environmental Science. https://doi.org/10.1088/1755-1315/120/1/012002.

Purba, N. P., Handyman, D. I. W., Pribadi, T. D., Syakti, A. D., Pranowo, W. S., Harvey, A., \& Ihsan, Y. N. (2019). Marine debris in Indonesia: A review of research and status. Marine Pollution Bulletin, 146(C), 134-144. https://doi.org/10.1016/j.marpolbul.2019.05.057.

Ratna, D. A. (2017). Pengaruh kadar air terhadap proses pengomposan sampah organik dengan metode takakura. Jurnal Teknik Mesin, 6(2), 124-128. https://doi.org/10.22441/jtm.v6i2.1192. 
Rahajeng Hasna Safira et al. / Geosfera Indonesia 6 (2), 2021, 157-172

Sahwan, F. L. (2010). Kualitas produk kompos dan karakteristik proses pengomposan sampah kota tanpa pemilahan awal. Jurnal Teknologi Lingkungan, 11(1), 79-85. https://doi.org/10.29122/jtl.v11i1.1225.

Selvam, K., Xavier, K. A. M., Shivakrishna, A., Bhutia, T. P., Kamat, S., \& Shenoy, L. (2020). Abundance, composition and sources of marine debris trawled-up in the fishing grounds along the north-east Arabian coast. Science of the Total Environment, 751(C), 141771. https://doi.org/10.1016/j.scitotenv.2020.141771.

Tarverdi, K. (2010). Improving the mechanical recycling and reuse of mixed plastics and polymer composites. Management, Recycling and Reuse of Waste Composites, Amsterdam : Elsevier.

Tchobanoglous, G., \& Kreith, F. (2002). Handbook of Solid Waste Management. New York: McGraw-Hill International.

UNEP (2014). Valuing Plastics: The Business Case for Measuring, Managing and Disclosing Plastic Use in the Consumer Goods Industry. Nairobi: U.N.E. Program.

United Nation ESCAP. (2012). Operational Manual on Composting for an Integrated Resource Recovery Center (IRRC). Bangkok: ESCAP.

United Nation ESCAP. (2015). Sustainable Development Goals. Bangkok: ESCAP.

UPK Badan Air. (2019). Rekapitulasi Volume Sampah UPK Badan Air November 2019. Retrived from : https://statistik.jakarta.go.id/.

Wahyono, S., \& Sahwan, F. (2010). Analisa biaya mekanisasi produksi kompos sistem windrow (studi kasus komposting di RPH Cakung-Jakarta Timur). Jurnal Teknologi Lingkungan, 11 (1), 87-93.

Waste Management Law (2008). Undang-Undang Republik Indonesia tentang Pengelolaan Sampah. Retrieved from https://peraturan.bpk.go.id/Home/Details/39067/uu-no-18tahun-2008.

World Bank Group. (2018). Hot Spot Sampah Laut Indonesia. Jakarta: World Bank.

Yusfi, R. N., \& Damanhuri, T. P. (2012). Studi Karakteristik dan Potensi Daur Ulang Sampah di Bantaran Sungai Cikapundung. Jurnal Teknik Lingkungan, 18(2), 155-166. https://doi.org/10.5614/jt1.2012.8.2.6. 